\title{
Samvirkni og samvinna í próunar- og umbótastarfi
}

\author{
Helga Sigríður Dórsdóttir og Anna Kristín Sigurðardóttir \\ Abstract Um höfundana $\backslash$ About the authors $>$ Heimildir
}

Samvirkni er af mörgum talin vera grundvöllur farsæls umbótastarfs sem leiðir til aukins árangurs í námi nemenda. Markmið rannsóknarinnar sem hér er til umfjöllunar er að öðlast skilning og pekkingu á pví hvernig samvirkni í stefnumótun í skólamálum birtist í premur sveitarfélögum á Íslandi, með pví að varpa ljósi á samskiptaform og vinnubrögð sem gætu stuðlað að eflingu og varanleika umbótastarfs. Kastljósinu var beint að áhrifum stefnumótunar sveitarfélaga á umbótastarf í skólum og hvernig vinnubrögð við stefnumótun og innleiðingu gæti mögulega ýtt undir eða hindrað varanlegar umbætur í skólastarfi að mati fræðslustjóra, skólastjórnenda og kennara.

Byggt er á kenningum um menntastjórnun sem hvetja til heiltækrar nálgunar til umbóta og eflingar forystu kennara svo drifkraftur peirra og pekking nýtist í skólapróun. Heiltæk nálgun tekur til flestra sviða skólastarfs og stuðlar að samvirkni (e. coherence) einstaka áhrifapátta, t.d. námskrár og kennsluhátta. Raunveruleg völd sveitarfélaga felast í samspili við stjórnendur og kennara skólanna.

Gagna var aflað með viðtölum við fræðslustjóra sveitarfélaganna, skólastjóra og meðlimi próunarteyma priggja skóla sömu sveitarfélaga. Einnig var rýnt í skólastefnur sveitarfélaganna og skólanna og ýmsar skýrslur um skólastarfið. Gögnin voru skoðuð með tilliti til priggja pátta: (1) hvernig skólastefnan verður til, (2) hvaða aðferðir eru notaðar við innleiðingu hennar og (3) hvernig stefnan birtist 1 viðhorfum kennara og í skólastarfinu.

Niðurstöđur benda til að meiri líkur séu á samvirkni í próunar- og umbótastarfi par sem unnið er eftir hugmyndafræði um faglegt lærdómssamfélag, stjórnendur veita faglega forystu, kennarar eru hafðir með í ráðum og samskipti skóla við skólaskrifstofu og fræðslustjóra byggja á trausti og fagmennsku. Par sem miðstýring er meiri spyrna kennarar frekar við fótum og upplifa skólastefnu sem kröfur um breytingar sem jafnvel samræmist ekki hugmyndum peirra um fagmennsku.

Efnisorð: Skólapróun, samvirkni, heiltæk nálgun til umbóta, dreifð forysta, faglegt lærdómssamfélag

\section{Inngangur}

Pað hefur vakið athygli rannsakenda á sviði skólapróunar að prátt fyrir að umbætur í skólamálum byggi almennt á góðri viðleitni til pess að gera skólastarfið betra, hafa pær ekki endilega skilað sér í breyttum kennsluháttum né betri námsárangri nemenda (Gerður G. Óskarsdóttir, 2014; European Agency for Special Needs and Inclusive Education, 2017). Samkvæmt niðurstöðum PISA-könnunar ársins 2015 og 2018 lídur íslenskum nemendum almennt vel í skólanum en námsárangur, m.a. í íslensku og stærðfræði, fer versnandi (Menntamálastofnun, 2019). Erfitt er 
að segja til um hvar orsökin liggur; í skólakerfinu sjálfu, tæknipróun eða uppeldi, en niðurstöður sýna fram á mikilvægi pess að leita leiða til pess að bæta menntun í landinu með árangursríkum hætti.

Mennta- og menningarmálaráduneyti, sveitarfélög og skólastjórar bera sameiginlega ábyrgð á gæðum skólastarfsins (Mennta- og menningarmálaráðuneytið, 2011). Gæðum skóla er viðhaldið meðal annars með ytra og innra mati á skólastarfi og viðeigandi umbótum í kjölfarið. Sveitarfélögum ber að móta skólastefnu og hafa virka skólanefnd, sem veitir aðhald og ráðgjöf í formi skólapjónustu svo umbætur í takt við stefnumótun verði að veruleika (lög um grunnskóla nr. 91/2008, 6. gr.). Raunveruleg völd og áhrif skólanefnda sveitarfélaga eru hins vegar óljós og felast einkum í samspili peirra við skólana (Guðmundur Ó. Ásmundsson, Börkur Hansen og Ólafur H. Jóhannsson, 2008), p.e. hvað úr stefnu sveitarfélagsins stjórnendur og kennarar kjósa að raungera í daglegu starfi. Augljóslega skapar petta vanda fyrir sveitarfélög sem vilja veita öfluga menntaforystu og vekur upp spurningar um hvort og pá hvernig hugmyndir kennara um eigin fagmennsku hafa áhrif á petta samspil. Vinna við innleiðingu skólastefnu gæti pví purft að fela í sér djúpar og tíðar samræður við kennara og stjórnendur eins og Robinson (2018) bendir reyndar á. Innleiðing aðalnámskrár frá 2011, stefna um skóla án aðgreiningar, vinnumat kennara og nýjar aðferðir við námsmat frá 2016 hafa valdið óróa meðal kennara sem upplifa pessar kröfur sem aukið vinnuálag. Peir benda m.a. á útgáfu Hvitbókar 2014 sem vísbendingu um aukna tilhneigingu til einhliða stefnumótunar um skólastarf af hálfu stjórnvalda og hafa gert athugasemdir við að Hvítbókin hafi verið unnin í litlu samráði við pá (Berglind Rós Magnúsdóttir, 2015; Skólamálarád Kennarasambands Íslands, 2016; Dorlákur Axel Jónsson, 2014). Nýjustu rannsóknir í menntamálum sýna fram á mikilvægi samvinnu lögađila og kennara í skólamálum par sem fagpekking kennara er nýtt á sviði skólabróunar pví breytingar purfa að spretta upp úr pörf fyrir pær í skólunum sjálfum, bæði til pess að tryggja innleiðingu peirra og gagnsemi (Anna Kristín Sigurðardóttir, 2019; Erla Björg Gunnarsdóttir, 2014; Hargreaves og Shirley, 2012; Hord og Roy, 2014).

Markmið rannsóknarinnar sem hér er til umfjöllunar er að öðlast skilning og pekkingu á pví hvernig samvirkni í stefnumótun í skólamálum birtist í premur sveitarfélögum á Íslandi, með pví að varpa ljósi á samskiptaform og vinnubrögð sem gætu stuðlað að eflingu og varanleika umbótastarfs. Megin rannsóknarspurningin er: Hvernig birtist samvirkni í stefnumótun sveitarfélaga og skóla?

Undirspurningar eru:

- Hvernig verður skólastefna sveitarfélaga og skóla til?

- Hvaða aðferðir eru notaðar við innleiðingu hennar?

- Hvernig birtast áhrif skólastefnunnar í viðhorfum kennara og í skólastarfinu?

Viðfangsefnið er skoðað í ljósi nýjustu rannsókna og kenninga um farsælar umbætur í skólastarfi og áhrifum stjórnunarhátta á pær. Dess er vænst að niðurstöður geti gefið vísbendingar um hvernig standa megi að innleiðingu nýjunga í skólastarfið og skapa vinnuumhverfi eða menningu par sem stöðugt er leitað leiða til pess að gera námið árangursríkara fyrir nemendur.

\section{Skólapróun og umbætur}

Skólastarf parf að próast í takt við samfélag hvers tíma. Hugmyndir um árangur eru síbreytilegar, en árangursríkt skólastarf nær eftirsóttum markmiðum á hverjum tíma (Hargreaves og Shirley, 2012). Umbætur í skólastarfi ganga út á að gera skólastarfið skilvirkara fyrir alla nemendur og snýst próunarstarf um að finna leiðir til pess (Hopkins, Stringfield, Harris, Stoll og Mackay, 2014). 
Hugtökin skólapróun (e. school development) og umbætur í skólastarfi (e. school improvement) eru gjarnan notuð jöfnum höndum til pess að skýra breytingastarf í skólum. Skólapróun eða próunarstarf er í núgildandi aðalnámskrá (Mennta- og menningarmálaráđuneytið, 2011) skilgreind sem „skipuleg, markviss og stöðug viðleitni til umbóta í skólum“ (bls. 63) og vísar gjarna til heildarskipulags til lengri tíma (Ólafur H. Jóhannsson, 2013). Robinson (2018) er ein peirra sem gerir skýran greinarmun á pessu tvennu. Hún bendir á að skólapróun sé hlutlaust hugtak yfir breytingar án tillits til pess að hverju pær beinast. Raunverulegar umbætur eru að hennar mati einungis pær breytingar sem bæta nám og líðan nemenda. Pessi greinarmunur er mikilvægur við ákvarðanatöku um menntabreytingar sem kosta tíma og orku fagfólks.

Cowan, Joyner og Beckwith (2012) telja að ákveðnar aðstæður í skóla séu æskilegar til pess að umbótastarf geti átt sér stað. Dær hafa sett fram eftirfarandi spurningar sem geta hjálpað skólastjórnendum til að meta hvort pær eru til staðar:

Er skólinn pannig gerður að hann komi auga á og bregðist við breytingum sem verða í umhverfinu? Ýtir skipulag skólans undir og styður við nýbreytni sem hjálpar kennurum og stjórnendum að bregðast við breytingum? Nær skólakerfið að halda athygli við nám og kennslu pegar aðstæður breytast? Er leitað að viðeigandi, nýlegum rannsóknum og bestu mögulegu aðferðum til pess að takast á við breytingar? (Cowan o.fl., 2012, bls. 11)

Ef hægt er að svara öllum pessum spurningum játandi er pað væntanlega vísbending um að skólinn sé tilbúinn í nauðsynlegar umbætur í skólastarfinu og að stuðla að markvissri skólapróun.

\section{Heiltæk nálgun og samvirkni}

Heiltæk nálgun til umbóta (e. systemic improvement) vísar til pess að umbætur ná til skólakerfisins alls, yfirvalda, skólastjórnenda, kennara, nemenda, foreldra og annarra hagsmunaaðila. Heiltæk nálgun nær einnig til pátta eins og stefnu, námskrár, námsefnis og kennsluaðferða svo fátt eitt sé nefnt (Anna Kristín Sigurðardóttir, 2019; Cowan o.fl., 2012; Hargreaves og Shirley, 2012). Heiltæk nálgun hvetur til samvinnu og skapar ákjósanleg skilyrði fyrir samvirkni í skólapróun sem er af mörgum talin vera grundvöllur farsælla umbóta og góðs árangurs nemenda (Cowan o.fl., 2012; Fullan og Quinn, 2016; Hopkins o.fl., 2014). Fullan og Quinn (2016) skilgreina samvirkni í grófum dráttum sem ákveðna vinnumenningu sem felst í hugarfari og gjörðum einstaklinga eða hópa sem vinna að sama markmiði. Pau halda pví fram að erfitt sé að stuðla að samvirkni, en með pví að hafa skýra sýn og rækta samvinnu- og samræðumenningu sem miðar að pví að dýpka nám nemenda, sé pað hægt. Robinson, Bendikson, Mcnaughton, Wilson og Zhu (2017) taka undir petta og telja að samvirkni verði best náð með samræðu og samvinnu sem miðar að pví að byggja upp sameiginlegan skilning fremur en með skýrum markmiðum og tékklistum sem vel er fylgst með. Dau eru pó alls ekki að gera lítið úr mikilvægi skýrra markmiða en leggja áherslu á að pau náist ekki með stýringu og eftirliti. Með heiltækri nálgun til umbóta er hægt að draga úr mótsögnum milli fræðsluyfirvalda og skóla og auka líkur á pví að umbætur verði varanlegar pegar pær snerta menntakerfið á fleiri en einu stigi pess og ná til fleiri sviða. Degar allt sem fram fer í skólastofunni rímar við markmið og stefnu skólans, fræðsluumdæmis og menntamálayfirvalda styður pað beint við námsárangur nemenda (Fullan, 2010).

Cowan o.fl. (2012) útskýra heiltæka nálgun til umbóta (e. whole system improvement) með premur víddum sem sýna mismunandi hliðar skólastarfsins sem taka parf tillit til í umbótaferlinu. Dessar víddir skólakerfisins skýra mismunandi stig, innihald og hæfni (Mynd 1). 


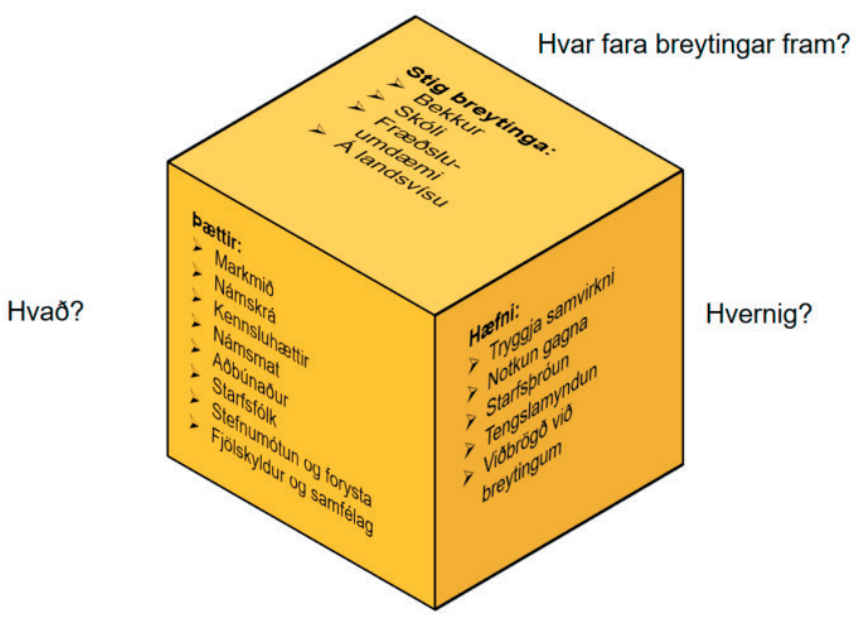

Mynd 1. Prjár víddir skólakerfisins (aðlagað frá Cowan o.fl., 2012, bls. 4).

Ef ráđist er í umbætur í skólastarfi er algengt að einblínt sé á einkenni vandamála en ekki orsök peirra. Umbætur eru oft of smáar í sniðum og smáviðgerðir (e. quick fix) eru gerðar í stað gagngerra breytinga og endast pví skammt. Ástæða pess er að orsakir vandamála eru gjarnan greiptar í menningu og starfshætti og pví erfitt að koma auga á pær. Einnig leggur fólk sjaldan í stórar breytingar í einu og pað er flókið að byggja upp hæfni til pess að próa skólastarfið á mörgum stigum pess samtímis (Cowan o.fl., 2012; Fullan, 2010). Til pess að koma á samvirkni í próunar- og umbótastarfi purfa markmið að vera skýr svo hægt sé að ná fram samhæfingu svo margra aðila, ríkja parf traust á milli peirra og samskipti að vera heiðarleg og góð. Í skólanum parf að vera áreiðanleg forystusveit, sterk meðvitund um gæði skólastarfsins og miklar væntingar til allra, jafnt skólastjórnenda, kennara og nemenda. Fullan (2016) tekur sérstaklega fram að gæðakennara sé ekki hægt að kaupa, pá verði að próa til starfsins inni í skólanum.

Hugmyndir um mikilvægi samvirknií umbótastarfi eru ekki nýtilkomnar. Fyrir tveimuráratugum benti Hopkins (2001) á nauðsyn pess að kennarar, skólastjórnendur og stefnumótunaraðilar ynnu saman að umbótum, (e. top-down vs. bottom-up) sem styður pá hugmynd að efla purfi bæði samstarf fyrrgreindra aðila og faglega forystu kennara. Fjölmargir fræðimenn hafa ítrekað pá skoðun síðan pá og bent á að slík vinnubrögð ýti undir dreifingu ábyrgðar og frumkvæði í skólastarfinu, kennarar öðlist fremur eignarhald á hugmyndum og grundvöllur umbótastarfs verði pannig styrktur (Börkur Hansen, 2013; Hargreaves, 2010; Harris, 2013; Hord og Roy, 2014; Robinson, 2018). Próunarstarf, umbótastarf og nýbreytni í skólastarfi reynir á starfsfólk og pví er mikilvægt að rannsaka hvers konar umgjörð í skólastarfi tryggir markvissa skólapróun og nauðsynlega innleiðingu umbóta.

\section{Hlutverk og ábyrgð einstakra stofnana í umbótastarfi}

Allar stofnanir og einstaklingar sem vinna að menntamálum í landinu bera ábyrgð á að skólastarf sé í stöðugri endurskoðun (Mennta- og menningarmálaráđuneytið, 2011). Hlutverk Mennta og menningarmálaráđuneytis er að gefa út aðalnámskrá, hafa eftirlit með gæðum skólastarfsins og styðja við próunarstarf í menntakerfinu (lög um grunnskóla nr. 91/2008, 4. gr.). Aðalnámskrá geymir sameiginleg markmið skólastarfs í landinu. Hún er bæði stjórntæki til pess að fylgja eftir grunnskólalögum sem og fyrirmæli fræðsluyfirvalda um skólastefnu (Mennta- og menningarmálaráðuneytið, 2011).

Sveitarfélögum ber að móta sér skólastefnu sem tekur mið af aðstæðum á hverjum stað. Í Handbók um gerð skólastefnu sveitarfélaga (Björk Ólafsdóttir, 2010) kemur fram að skólastefna segi til um hvernig skólar sveitarfélagsins eigi að vera innan ákveðins tíma. Stefnumótun snýst um að útbúa vegvísi í skólapróun fyrir sveitarfélagið og stefnan inniheldur pví hugmyndir að leiðum, 
sem stjórna pví hvernig settu marki verður náð. Í sömu handbók segir enn fremur: „Skýr og skráð gildi, hlutverk, framtíðarsýn, markmið og árangursmælingar eru grundvallaratriði í mótun skólastefnu“ (bls. 7). Bæði í Handbók um gerð skólastefnu og í aðalnámskrá er kveðið skýrt á um að stefnumótun um skólamál eigi að fara fram í víðtæku samráði við hlutaðeigandi aðila (Björk Ólafsdóttir, 2010; Mennta- og menningarmálaráðuneytið, 2011) en ekki liggja fyrir upplýsingar um hvort petta sé almennt raunin hér á landi. Bent hefur verið á pá óvissu sem sveitarfélög og aðrir stefnumótunaraðilar standa frammi fyrir pegar kemur að innleiðingu stefnunnar (Guðmundur Ó. Ásmundsson o.fl., 2008). Kennarar og stjórnendur ákveða hvað úr stefnunni peir leggja áherslu á og hvernig peir innleiða pað í daglegt skólastarf. Stefnumótunaraðilar reiða sig pví á faglega dómgreind kennara og purfa að haga nálgun og aðferðum til samræmis við pað (Anna Kristín Sigurðardóttir, 2019; Milner, 2013; Robinson o.fl., 2017).

Samkvæmt núgildandi aðalnámskrá (Mennta- og menningarmálaráđuneytið, 2011) ber skólastjóra að sjá um gerð skólanámskrár og starfsáætlunar í samráđi við kennara og starfsfólk. Með pátttöku í samráðinu má líta svo á að starfsmenn hafi skuldbundið sig til að framfylgja áætlununum. Í skólanámskrá á m.a. að geta um áæetlanir í umbóta- og próunarstarfi, en í starfsáætlun á að gera grein fyrir símenntunaráætlunum skólans. Í flestum tilfellum er talað um próunar- og umbótastarf sem sameiginlegt verkefni allra sem að skólastarfinu koma en pegar reglugerðir eru rýndar koma pessi hugtök skýrast fram í starfssviði skólastjóra og kennara eins og Ingólfur Ásgeir Jóhannesson (2013) bendir á eftir að hafa rýnt í orðalag laga og reglugerða.

\section{Stjórnun og forysta}

Stjórnun og forysta er mikilvægur páttur í að skapa ákjósanlegar aðstæður til náms og kennslu í sveitarfélaginu. Fræðslustjóri hefur yfirumsjón með að skólastarfið fari rétt fram en skólastjórinn ber ábyrgð á skólastarfinu, par sem hann leiðir saman ýmsa hópa og samhæfir störf peirra (Börkur Hansen, 2013). Hlutverk pessara aðila er að stuðla að samvirkni í skólastarfi og veita faglega forystu við stefnumótun og innleiðingu nýjunga sem hafa pað að markmiði að skapa sem bestar aðstæður til náms fyrir nemendur.

Hugmyndir og kröfur til forystuhlutverka í skólastarfi eru sífellt að breytast. Frá pví að forysta almennt tengdist fyrst og fremst stjórnandanum og persónu hans, snýst forysta í skólastarfi nú í auknum mæli um hvað stjórnendur gera til pess að dreifa forystunni (e. distributed leadership) og valdefla (e. empower starfffólkið (Ash og Hodge, 2016). Valdefling verður til pegar stjórnendur hvetja aðra til pess að hafa áhrif og styðja pá á uppbyggilegan hátt svo að hugmyndir peirra nái fram að ganga (Hoy og Miskel, 2013). Sá sem valdeflir slítur valdið frá stjórnunarstöðunni og deilir pví með fleirum. Valdefling leiðir af sér dreifða forystu.

Í kjölfar pess að starfsemi skóla hefur orðið flóknari með árunum hvetja fræðimenn til dreifðar forystu og benda á kosti pess að leggja ábyrgð og ákvarðanatöku í hendur fleiri einstaklinga (Harris, 2013). Í dreifðri forystu er líklegra að fólk vinni að málefnum sem pað hefur áhuga á, par af leiðandi aukast líkur pess að pau verði unnin til fullnustu. Ef ábyrgð og ákvörðunartöku er deilt með kennurum má reikna með að eignarhald hugmynda verði hjá peim, peir valdeflist og vinni að peim af áhuga og stolti. Dreifð forysta getur pví verið öflugt hreyfiafl próunar (Börkur Hansen, 2013). Í niðurstöðum rannsóknar Amalíu Björnsdóttur, Barkar Hansen og Ólafs H. Jóhannessonar (2006) kemur fram að kennarar á Íslandi vilji gjarnan hafa meiri áhrif á mótun skólastarfs en peir hafa nú. Pau leggja til að kennarar fái meira vægi i ákvarðanatöku og við mótun skólastarfsins, t.d. með pví að nota gögn peirra og hugmyndir úr skólastarfinu í stefnumótun.

Fullan (2016) segir að farsælu umbótastarfi fylgi óhjákvæmilega faglegt nám og pví sé skipulag á starfspróun kennara hluti af hlutverkum stjórnenda. Robinson, Hohepa og Lloyd (2009) eru sama sinnis og halda pví fram að pátttaka skólastjórnenda í faglegu námi og starfspróun kennara geti haft afgerandi áhrif á námsárangur nemenda. Með pví að beina athyglinni að pví sem gerist í skólastofunni fá skólastjórnendur betri yfirsýn yfir kennsluhætti og kynnast pví 
sem kennarar eru að fást við. Deir verða líklegri til að veita kennurum stuðning í starfi og eru sveigjanlegri við skipulag skólastarfsins í heild. Pannig starfshættir auka samvirkni í skólastarfi og gera pað árangursríkara (Robinson o.fl., 2009). Skólastjórar á Íslandi eru meðvitaðir um petta en benda á að álag og tímaleysi rýri möguleika peirra til faglegrar forystu og kennarar kvarta undan skorti á viðeigandi endurmenntunar- og starfspróunarmöguleikum tengdum nýjungum í skólastarfi (Birna Sigurjónsdóttir og Börkur Hansen, 2014). Kennarar vilja hafa áhrif á eigin starfspróun og hafa rannsóknir sýnt að par sem peir hafa umsjón með henni sjálfir og er treyst fyrir skipulaginu, hefur pað jákvæð áhrif á faglegt nám peirra og kemur nemendum til góða (Campbell, Liebermann og Yashkina, 2016). Margt bendir til að starfspróun kennara sé öflugust í faglegu lærdómssamfélagi.

\section{Faglegt lærdómssamfélag kennara}

Faglegt lærdómssamfélag kennara (e. professional learning community) í skólum er vinnumenning sem að margra mati stuðlar að frampróun skólakerfisins. Раð byggir á hugmyndinni um að kennarar vinni saman að pví að móta skólastarfið og séu pví lykilaðilar í stefnumótun um skólastarf. Í faglegu lærdómssamfélagi ríkir sameiginleg sýn, forysta er dreifð og kennarar læra hver með öðrum og hver af öðrum. Par ríkir gagnkvæmur stuðningur samstarfsfólks og stjórnenda par sem starfsfólk miðlar hugmyndum og aðferðum um betri kennslu. Í lærdómssamfélagi setur starfsfólkið sér langtímamarkmið, skilgreinir leiðir til pess að ná peim og ígrundar saman afleiðingar aðgerða sinna með hjálp hlutlægra gagna. Sú gagnrýna ígrundun og samvinna sem felst ílærdómssamfélagi er að margra mati talin vera lykill að árangursríku skólastarfi (Anna Kristín Sigurðardóttir, 2013; Dogan og Adams, 2018; Hord, 2004). Dannig verða kennarar bæði eigendur pekkingarinnar og ákvarðana sem koma í kjölfarið. Hargreaves og Fullan (2012) og Hord (2004) tala um kraftinn sem myndast í jafningjahópnum við slíkar aðstæður, par sem samskipti eru góð, traust ríkir og fólk trúir á getu hver annars (e. collective efficacy) (Anna Kristín Sigurðardóttir, 2013; DuFour og DuFour, 2012; Hord og Roy, 2014).

Lykilpáttur að góðu lærdómssamfélagi er að skólastjóri sé faglegur leiðtogi kennara sem bæði leiðir pá áfram og veitir peim stuðning. Í pessu samhengi nefnir Fullan (2016) mikilvægi pess að skólastjóri búi yfir góðri pekkingu á faglegu starfi og kennslufræði til pess að geta veitt forystu í lærdómssamfélagi. Î pví felst meðal annars að skólastjóri komi með ábendingar, sýni áhuga á starfi kennaranna, hrósi peim, sé hvetjandi og styðjandi líkt og kenningar Lambert (2006) kveða á um. Slíkir starfshættir skila sér ekki aðeins í hvetjandi starfsumhverfi heldur hafa peir einnig góð áhrif á virkni og samvinnu kennara.

\section{Aðferð}

Rannsóknin var hluti af stærri rannsókn rannsóknarteymis á Menntavísindasviði sem ber heitið „Að bera meira úr býtum“- BMB, sem náði yfir tveggja ára tímabil (2016-2018) og beindist að premur skólaskrifstofum, premur próunarskólum, skólastjórum peirra og próunarteymum. Tilgangur BMB-rannsóknarinnar var: Í fyrsta lagi að greina og skilja árangursríkt ferli breytinga í skólastarfi grunnskóla, í öđru lagi að varpa ljósi á hvernig pað tengist stöðu skóla sem lærdómssamfélags og í priðja lagi að draga fram atriði sem gætu útskýrt árangur eða árangursleysi umbótastarfs (Háskóli Íslands, e.d.). Sá hluti rannsóknarinnar sem fjallað er um hér tengist samhengi í stefnumótun frá sveitarfélagi og inn í skólastofuna.

Dátttakendur í rannsókninni voru prjú sveitarfélög og prír skólar sem voru valin af BMBrannsóknarhópnum (Tafla 1). BMB-rannsóknin er tilviksrannsókn og voru sveitarfélögin valin af hagkvæmnisástæðum (Katrín Blöndal og Sigríður Halldórsdóttir, 2013). Nöfn allra skóla viðkomandi sveitarfélaga voru sett í prjá potta og nöfn 13 skóla dregin út. Af pessum prettán var fjórum skólum boðið að taka pátt og birtast gögn frá premur peirra í pessari rannsókn, frá einum úr hverju sveitarfélagi. Í yfirliti (sjá Töflu 1) yfir pátttakendur í rannsókninni koma fram 
gervinöfn sem sveitarfélögunum og skólunum hafa verið gefin og verða notuð í pessari grein. Detta er gert til pess að tryggja trúnað við pátttakendur.

Tafla 1. Yfirlit yfir pátttakendur í rannsókninni.

\begin{tabular}{lll}
\hline Skólaskrifstofa Reynisvogs & Skólaskrifstofa Fjallabæjar & Skólaskrifstofa Skriðuvíkur \\
Skólastjóri Reynisskóla & Skólastjóri Fjallaskóla & Skólastjóri Skriðuskóla \\
Dróunarteymi Reynisskóla & Próunarteymi Fjallaskóla & Dróunarteymi Skriðuskóla \\
\hline
\end{tabular}

Af sömu ástæðu eru engar upplýsingar gefnar um stærð sveitarfélaga og skólaskrifstofa, fjölda skóla í sveitarfélagi eða stærð skóla. Talað er um alla pátttakendur í karlkyni í samræmi við kyn orðanna stjóri og kennari.

\section{Gagnaöflun og úrvinnsla}

Einstaklingsviðtöl voru tekin við fræðslustjóra í sveitarfélögunum premur og skólastjórana prjá. Eitt hópviðtal var auk pess tekið við próunarteymi hvers skóla (Tafla 2). Próunarteymin voru skipuð af stjórnendateymi hvers skóla, fjórir til sex einstaklingar voru í hverju peirra. Viðtölin fóru fram á vinnustöðum viðkomandi. Flest viðtölin voru tekin við upphaf verkefnisins, en auk pess var annað viðtal tekið við tvo af fræðslustjórunum í lok pess. Notast var við hálfstaðlaðan viðtalsramma sem beindist að pví að draga fram upplýsingar um vinnubrögð og viðhorf viðkomandi til stefnumótunar og umbótastarfs.

Önnur gögn voru skólastefnur, ársskýrslur og/eđa starfsáætlanir pessara sömu skóla og sveitarfélaga og sjálfsmatsskýrslur skólanna. Gögnin voru öll fengin af opinberum vefsíðum (sjá Töflu 2) sem rýnt var í til að fá dýpri innsýn í stefnumörkun skólanna og sveitarfélaganna en viðtölin gáfu.

Tafla 2. Yfirlit yfir gagnasafnið.

\begin{tabular}{|c|c|c|c|}
\hline Viðtal við: & Reynisvogur & Fjallabær & Skriðuvík \\
\hline \multirow[t]{2}{*}{ Fræðslustjóra } & \multirow[t]{2}{*}{1 viðtal í 50 mín. } & 1 viðtal í 50 mín. & 1 viðtal í 53 mín. \\
\hline & & 1 viðtal í 34 mín. & 1 viðtal í 23 mín. \\
\hline Skólastjóra & 1 viðtal í 55 mín. & 1 viðtal í 54 mín. & 1 viðtal í 70 mín. \\
\hline Dróunarteymi & $\begin{array}{l}1 \text { hópviðtal við } \\
\text { fimm í } 50 \text { mín. }\end{array}$ & $\begin{array}{l}1 \text { hópviðtal við fjóra í } \\
80 \text { mín. }\end{array}$ & $\begin{array}{l}1 \text { hópviðtal við sex í } 57 \\
\text { mín. }\end{array}$ \\
\hline \multirow{3}{*}{$\begin{array}{l}\text { Fyrirliggjandi } \\
\text { gögn frá } \\
\text { sveitarfélagi: }\end{array}$} & \multirow{2}{*}{$\begin{array}{l}\text { Stefna og } \\
\text { starfsáæetlun } \\
\text { 2016, } 22 \text { bls. og } \\
\text { fylgiskjöl. }\end{array}$} & $\begin{array}{l}\text { Lestrarstefna fyrir leik- } \\
\text { og grunnskóla, } 5 \text { bls. }\end{array}$ & $\begin{array}{l}\text { Skólastefna sveitarfélags } \\
\text { 2013-2016, } 19 \text { bls. }\end{array}$ \\
\hline & & $\begin{array}{l}\text { Skólastefna Fjallabæjar } \\
\text { til ársins 2017, } 6 \text { bls. }\end{array}$ & $\begin{array}{l}\text { Ársskýrslur fræðslusviðs } \\
2014 \text { og } 2015 \text { hvor um }\end{array}$ \\
\hline & $\begin{array}{l}\text { Stefna og } \\
\text { starfsáætlun } \\
\text { 2015, } 23 \text { bls. og } \\
\text { fylgiskjöl. }\end{array}$ & $\begin{array}{l}\text { Stefna Fjallabæjar } \\
\text { í breyttum } \\
\text { kennsluháttum, } 10 \text { bls. }\end{array}$ & $\begin{array}{l}\text { sig } 45 \text { bls. } \\
\text { Aðrar skýrslur og } \\
\text { fyrirlestraefni } 35 \text { bls. }\end{array}$ \\
\hline \multirow[t]{3}{*}{$\begin{array}{l}\text { Fyrirliggjandi } \\
\text { gögn frá skóla: }\end{array}$} & $\begin{array}{l}\text { Stefna skóla, } 2 \text { bls. } \\
\text { Starfsáætlun 2016- } \\
\text { 2017, } 54 \text { bls. }\end{array}$ & \multirow{2}{*}{$\begin{array}{l}\text { Stefna skóla, } 1 \text { bls. } \\
\text { Skólanámskrá, } \\
\text { Starfsáætlun 2016- } \\
\text { 2017, } 43 \text { bls. }\end{array}$} & $\begin{array}{l}\text { Starfsáætlun 2016-2017, } \\
26 \text { bls. } \\
\text { Sjálfsmatsskýrsla 2015- }\end{array}$ \\
\hline & \multirow{2}{*}{$\begin{array}{l}\text { Yfirlit yfir } \\
\text { sjálfsmats tæki } \\
\text { skólans, } 1 \text { bls. }\end{array}$} & & 2016, 61 bls. \\
\hline & & $\begin{array}{l}\text { Listi yfir próunar- } \\
\text { verkefni, } 1 \text { bls. }\end{array}$ & $\begin{array}{l}\text { Leiðarljós starfsmanna, } \\
1 \text { bls. }\end{array}$ \\
\hline
\end{tabular}


Söfnun fyrirliggjandi gagna frá skólaskrifstofum fór fram á prjá vegu. Annaðhvort afhentu fræðslustjórar eintök af stefnum og ársskýrslum í viðtalinu sjálfu, pær voru sóttar á heimasíður sveitarfélaganna eða beðið var um pær í tölvupósti eftir á.

Viðtölin voru pemagreind (Braun og Clarke, 2013) með раð аð markmiði að draga fram sem heildstæðasta mynd af peim skilyrðum sem purfa að vera til staðar innan grunnskóla og sveitarfélaga og í samstarfi peirra svo innleiðing umbóta á skólastarfi gangi farsællega. Niðurstöður gefa vísbendingar um hvernig staðið er að stefnumótun og próunarstarfi í pessum premur sveitarfélögum og skólum án pess að alhæfa yfir á aðra skóla eða sveitarfélög. Bess er pó vænst að draga megi lærdóm af niðurstöðum fyrir önnur sveitarfélög á Íslandi. Tilgangurinn er ekki að bera saman sveitarfélögin og skólana heldur að draga fram sameiginlega præði eða pemu.

\section{Niðurstöður}

Greint er frá niðurstöðum með hliðsjón af undirspurningum rannsóknarinnar. Đær varða hvernig skólastefna sveitarfélaga og skóla verður til, hvaða aðferðir eru notaðar við innleiðingu stefnunnar í skóla sveitarfélagsins og hvernig áhrif hennar birtast í viðhorfum kennara og í skólastarfinu.

\section{Mótun skólastefnu}

Stefnumótun skólanna í rannsókninni byggir á skólastefnum sveitarfélaganna, gildum, kenningum og hugmyndafræði er varðar farsælt skólastarf, en ganga mislangt í pví að skilgreina hvernig nám og kennsla eiga að fara fram. Fjallaskóli og Skriðuskóli eru u.p.b. jafn gamlir skólar, annar skólinn mótaði sér skýra stefnu frá upphafi sem nýtist enn pann í dag, á meðan hinn hefur vaxið upp úr stefnunni sem sett var í byrjun og vinnur að endurnýjun hennar. Elsti skólinn í hópnum, Reynisskóli, mótaði sér óljósa stefnu með einkunnarorðum, leiðarljósi og uppeldisstefnu fyrir átta árum.

Skólastefna sveitarfélagsins Reynisvogs hefur undanfarin ár mótast á skólaskrifstofunni án mikillar aðkomu skólafólks að sögn fræðslustjóra, en hugmyndir eru uppi um að breyta pví og fá fleiri аð borðinu. Stefna hvers árs er ýtarleg og gengur út frá ákveðnum áherslupáttum hverju sinni. Á heimasíðu Reynisskóla voru engar upplýsingar um núverandi skólastefnu sveitarfélagsins, en aðspurður um stefnu skólans í námi og kennslu sagði kennari í Reynisskóla: „Бað er ekki svona fyrir fram ákveðið allt, svona nákvæmlega hvernig á að bregðast við öllu. Рað er svona frelsi til að bregðast við á mismunandi hátt.“ Að sögn kennara tilheyrir pað menningu skólans að fagmennsku peirra sé treyst og hverjum og einum er frjálst að fara sínar eigin leiðir í mótun kennsluhátta. Kennarinn hélt áfram: „Баð er mikið ... rætt um fagmennsku hérna innan húss ... [meðal] allra pessara aðila; stjórnenda, kennara og annarra og svona „basically“ pá er bara fagmennsku kennara treyst pangað til annað kemur í ljós." Af pessu má ráđa að fagleg umræða sé töluverð að mati starfsfólks og peir telji inngreypt í skólamenninguna að hverju sé stefnt. Ef annað kemur á daginn og fólk villist af leið telja peir að brugðist sé við pví af hálfu skólastjórnenda án pess pó að dæmi um pað hafi verið nefnd.

Í Skriðuvík er sterk samstaða um að „fá sem flesta að borðinu“ við stefnumótun um skólastarf að sögn fræðslustjóra. Hann sagði unnið eftir hugmyndafræði lærdómssamfélagsins og lætur skólanefndin fræðslustjóranum eftir að leiða skólamálin samkvæmt peirri hugmyndafræði. „Фаð er ekki mikið um að frumkvæðið komi frá [pólitískum] yfirvöldum fræðslumála. Miklu meira frumkvæði kemur frá skólasamfélaginu og mér finnst pað bara mjög gott.“ Fræðslustjórinn tekur við ábendingum úr skólasamfélaginu og honum er treyst til að vinna með og styðja við hugmyndir sem koma paðan. Hann tók fram að við undirbúning síðustu skólastefnu Skriðuvíkur hafi m.a. verið settur upp ábendingavefur á netinu par sem íbúar fengu tækifæri til pess að koma fram með sínar hugmyndir. Í síðara viðtali staðfesti fræðslustjóri að enn lengra hefði verið gengið í að tengja skólaskrifstofu og kennara í skólunum og nefndi hann nokkur dæmi pví til 
staðfestingar. Hann lýsti pví hvernig hann vann með kennurum að ákveðnu verkefni: „Ég var í kennarahópum ... par sem við fórum gagnrýnið yfir hvernig við erum að gera petta og hvernig viljum við hafa petta ... petta var ofboðslega gagnlegt fyrir mig ... að fá ekki bara skilaboð frá skólastjórnendum heldur líka beint frá kennurum. “ Fræðslustjórinn skynjaði afslappað og jákvæett andrúmsloft gagnvart skólaskrifstofunni.

Stefna Skriðuskóla er ólík stefnum hinna skólanna pví hún byggir á pví sem skólastjórinn kallaði grundvöll starfsins, sem var markaður áður en skólinn var byggður. Dá var ákveðin hugmyndafræði notuð sem byggir á pví að hanna stefnu, kennsluhætti og húsnæðið samhliða. Detta ferli fór fram í samstarfi fagaðila í skólakerfinu, arkitekta og fulltrúa bæjarsamfélagsins. Grundvöllurinn var síðan notaður til pess að móta kennsluhætti og marka frekari stefnu fyrir framtíðina. Stefnumótun nú á dögum byggir á niðurstöðum úr innra mati um hvað gera megi betur til pess að uppfylla stefnuna.

Í Fjallabæ er skólastefnan pólitískt mótuð, en par eins og í Skriðuvík hefur fulltrúum úr skólasamfélaginu, stjórnendum, kennurum og foreldrum verið boðin pátttaka í stefnumótuninni í meiri mæli en áður. Fræðslustjóra Fjallabæjar fannst gott að hafa skýra stefnu frá sveitarstjórninni, sagði pað styrkja starf skólaskrifstofunnar og tryggja fé í verkefnin. Skólastjóri Fjallaskóla hefur fengið tilmæli frá skólaskrifstofunni að koma á ákveðnum starfsháttum í skólanum svo peir samræmist skólastefnu sveitarfélagsins og er nú unnið að mótun skólastefnu. Ljóst var að mörg verkefni voru í gangi í einu, sem var misvel fylgt eftir af skólayfirvöldum. Skólastjórinn sagðist safna ýmsum gögnum um skólastarfið, skoða eldri gögn, ræða við sína nánustu samstarfsmenn og fá kennara til viðtals við sig. Auk pess sagði hann marga hópa innan skólans vinna að stefnumótun.

\section{Innleiðing skólastefnu}

Innleiðing skólastefnu snýst um að koma skólastefnu sveitarfélags og skóla í framkvæmd. Sveitarfélögin prjú bjóða reglulega upp á námskeið fyrir kennara og gefa út stefnur og skýrslur um hin ýmsu málefni, en áherslur í hugmyndafræði og mismunandi vinnuhefðir í sveitarfélögunum gera innleiðingarferli peirra ólík.

Í rannsókninni greindu fræðslustjórar Fjallabæjar og Skriðuvíkur frá nýafstaðinni innleiðingu á ákveðnum páttum úr skólastefnunni og verða pessi dæmi notuð til pess að skýra vinnubrögð og hugmyndafræði. Dæmið frá Fjallabæ sýnir hvernig unnið er að innleiðingu mjög viðamikils verkefnis á meðan dæmið frá Skriðuvík gefur mynd af pví hvernig hugmyndafræði skólasamfélagsins mótar stefnugerð og innleiðingu. Í Reynisvogi er unnið að innleiðingu nýs námsmats en Reynisskóli vinnur að innleiðingu fleiri pátta úr aðalnámskrá frá 2011 og á skólinn nokkuð verk fyrir höndum.

Í Fjallabæ réð skólaskrifstofan verkefnastjóra og sérstaka kennsluráđgjafa í hvern skóla til pess að innleiða breytingar á kennsluháttum. Fræðslustjórinn taldi að vel hefði gengið og sagði pað vera bæjarstjórninni að pakka: „Darna studdi pólitíkin rosalega vel við okkur“, og á pá við bæði fjárhagslega og hugmyndafræðilega. Hann lagði áherslu á hversu mikilvægt pað væri að hafa skólastjórana á sínu bandi:

Við erum náttúrulega með skólastjórnendur alltaf með okkur pví pað skiptir ofboðslega miklu máli að peir séu við stýrið í innleiðingunni og að peir séu ... efldir. ... við, ég og verkefnastjóri ... og kennsluráðgjafarnir, héldum peim inni allan tímann ... Hvernig við ættum að gera petta? Hvað ætti að gera?

Hann lýsti pví hvernig hann pétti raðirnar meðal skólastjórnenda og stjórnenda verkefnisins og tryggði peim pátttöku í mótun pess frá upphafi. Tilgangurinn var að allir fengju yfirsýn yfir verkefnið, og pað sjálfstraust sem purfti til að leiða pað úti í skólunum. Í tengslum við verkefnið hélt fræðslustjórinn stefnumótunarfundi og námskeið fyrir skólastjórnendur og bauð peim með 
sér í skólaheimsóknir erlendis. Í framhaldinu „voru stofnuð ... innleiðingarteymi ... í hverjum einasta skóla“. Um innleiðingarferlið sagði hann: ,... Við höfðum ... ár til pess að undirbúa, halda námskeið, fara í heimsóknir, skoða, velta fyrir okkur." Námskeið voru haldin bæði fyrir kennara og foreldra. Drátt fyrir allan pennan áhuga í byrjun og allt petta kynningarstarf og ráðgjöf sagði fræðslustjórinn marga „upplifa að pessu hafi verið skellt á pá““ ofan frá sem skapaði vissa andstöðu.

Í Skriðuvík svipar margt til vinnubragða í Fjallabæ, en opnari skólamenning og almennari samvinna um marga hluti gera innleiðingarferlin ólík. Fræðslustjóri Skriðuvíkur sagði að ekki væri um eiginlegt innleiðingarferli að ræða heldur tækju margir pátt í mótun skólastarfsins. Pátttakendur yrðu par af leiðandi eigendur hugmynda sem gerði innleiðingu umbóta að eðlilegum hluta af daglegu skólastarfi. Fræðslustjórinn sagði frá skólapingi og málstofum par sem kennarar og starfsmenn skólanna kynntu vinnu sína og hugmyndir með pað að markmiði að læra hver af öðrum. Við nánari eftirgrennslan um innleiðingu nýjunga eða umbótavinnu tók fræðslustjórinn alltaf fram hvernig umbótaverkefnið kom til, hverjir áttu hugmyndina og hvernig hún próaðist í samvinnu fleiri aðila, eins og eftirfarandi dæmi sýnir:

Við [erum] mjög upptekin af pví að fá alla með okkur í pví að móta pessar áherslur, að petta komi .... af gólfinu sem mest. Auðvitað erum við öll saman í pessu pannig að kennarar og stjórnendur í skólunum finni að peir hafi eitthvað að segja um próun skólastarfsins.

Í sveitarfélaginu er lögð mikil áhersla á samvinnu kennara og starfsfólks við mótun skólastefnunnar. Mikilvægt er að sem flestir finni að peir hafi fengið að koma fram með sínar hugmyndir og pað sé tekið mark á peim.

Fræðslustjóri Skriðuvíkur sagðist reyna að ýta undir frumkvæði kennara og stjórnenda. „Баð er mottó hjá okkur að ef einhver kennari eða stjórnandi kemur og segir að peir hafi pörf fyrir eitthvað, pá reynum við verða við pví." Sem dæmi nefndi hann kennara sem fréttu aflærdómsríku námskeiði í tengslum við ípróttir og nýju aðalnámskrána:

Deir nefndu pað, ... hefði verið [...] flott námskeið í [næsta bæ], fyrir ípróttakennara ...Ég tók pá bara á orðinu og við sóttum um styrk ... í endurmenntunarsjóð til pess að halda námskeið, sem við buðum reyndar ípróttakennurum í nágrenninu að taka pátt í.

Fræðslustjóri Skriðuvíkur nefndi annað verkefni, en viðtaka pess lýsir ágætlega viðhorfi kennara til fjölda próunar- og umbótaverkefna. Hann sagði:

Risaverkefni, en kannski ekki eins flókið eins og fólk hélt fyrst. ... Petta er bara í beinu framhaldi af öllu hinu um námsmat. Sumir voru að segja: „Er petta eitt verkefnið enn eða einhver viðbót?" Svo er fólk náttúrulega farið að átta sig á pví núna að petta er bara eitthvað sem við erum að gera og eigum að gera og í beinu framhaldi af öllu hinu.

Fræðslustjórinn hafði tekið eftir viðhorfsbreytingu meðal kennara og sagði að peir væru farnir að skilja að skólastarfið pyrfti að vera í stöðugri próun og umbótaverkefnum myndi aldrei ljúka. Hann nefndi einnig að pau hefðu lagt áherslu á að vinna markvisst með kennurum og stjórnendum 1 að rýna í gögn um árangur starfsins, en hann taldi pó að parna mætti gera mun betur.

Öllum fræðslustjórunum bar saman um að skólastjórar væru lykilpersónur í skólapróun og lögðu áherslu á góð samskipti við pá. Eitt helsta markmið fræðslustjóranna er pví að styrkja skólastjóra í leiðtogahlutverkinu eins og fræðslustjóri Reynisvogs komst að orði: „Að við séum fyrst og fremst аð styðja ... við pá pannig að peir geti orðið öruggir í pví að halda síðan áfram með petta niður ... minnka tilfinninguna fyrir pví að pað komi tilskipun að ofan.“

Fræðslustjóri Reynisvogs sagði skóla sveitarfélagsins mjög sjálfstæða og í Fjallabæ hefur ekki tíðkast að fræðslustjórinn fari sjálfur inn í skólana, par af leiðandi er gott samband við skólastjórana 
lykilatriði. Fræðslustjóri Skriðuvíkur virðist hafa meira samstarf við bæði skólastjóra og kennara enda minna umdæmi. Hann vitnaði oft í að kennarar kæmu til fundar við sig eða litu við á skólaskrifstofunni með erindi. Prátt fyrir petta taldi hann sig ekki hafa fulla stjórn á innleiðingu stefnunnar enda samræmdist pað ekki hugmyndafræði lærdómssamfélagsins sem sveitarfélagið hefur einsett sér að vinna eftir, heldur skipti gagnkvæmt traust mestu máli.

\section{Áhrif skólastefnunnar á viðhorf kennara og skólastarf}

Í Reynisskóla í Reynisvogi stóð yfir undirbúningur að innleiðingu á aðalnámskrá og nýju námsmati í öllum árgöngum. Innleiðingarferlið var nýhafið og kennarar unnu að umbótum á námskrá og námsmati. Pað gætti viss ráđaleysis hjá kennurum gagnvart verkefninu og augljóst að ekki voru allir með á hreinu hvert stefndi. Aðstoðarskólastjóri Reynisskóla hafði orð á pví að pað skorti hugmyndafræðilega forystu hjá sveitarfélaginu og fannst hann pvingaður út í breytingar sem voru illa undirbúnar:

Já, ég verð nú bara að segja eins og er, ... ég ætla ekki að fara að nefna hvorki einn eða neinn, en ... mér finnst losarabragur á svo mörgu og svo mikil vitleysa í svo mörgum hlutum, jafnvel einhverjum smáatriðum.

Skólastjórinn tók undir pessi orð og fannst hann purfa að vera með mörg járn í eldinum til pess að vinna samkvæmt stefnu sveitarfélagsins. Honum fannst endalaust verið að prýsta á með ný verkefni í stað pess að taka tillit til sérkenna hverrar stofnunar og að leiðbeina hverjum skóla fyrir sig. Skólastjóranum fannst hann ekki hafa yfirsýn yfir pað sem ætlast væri til af honum og skólaskrifstofan gera miklar kröfur með of mörgum verkefnum. Kennari í próunarteyminu tók í sama streng og taldi að skólaskrifstofan ætti að veita meiri leiðsögn, hún ætti að „,vera einhverjum skrefum á undan, $[\mathrm{og}]$ ekki að láta taka sig í bólinu“ eins og hann orðaði pað. Hún ætti að vera í leiðtogahlutverki og geta komið til móts við skólana pegar skólarnir kölluðu eftir pví. Kennari í Reynisskóla sagði að hingað til hefði skipulagi um próunarstarf verið ábótavant: „,... pað er kannski ekkert á tæru hver á að sjá um pað, pannig að pað er hætta á að pað dagi uppi.“ Hann benti hér á að pað vantaði skipulagt ferli í kringum próunarstarf í skólanum, til dæmis að upplýsingar um árangur væru teknar saman og unnið með pær. Annar kennari tók í sama streng og sagði:

Umbótavinnan hefur verið til pess að stuðla að einhverju,spjalla saman,lærdómssamfélagið og allt pað ... Svo fer vitneskjan að fljóta of mikið ... og hver og einn gerir með hana pað sem hann ... [vill].

Kennararnir virtust sjá árangur af umbótafundum og hafa gaman af pví að vinna með öðrum, en söknuðu pess að umbótatillögum væri fylgt betur eftir til úrbóta í skólastarfinu: „,Ég hugsa alltaf bara, ég ætla að klára mína kennslu fyrst, síðan sinna mínum bekk, gott samstarf við foreldra, standa alveg klár á pví ... er [betta] ekki líka spurning um tíma?" Árangursleysi umbótastarfsins var kennurum að hluta til ljóst, en peim fannst skipta meira máli að sinna kennslunni vel, en að vera „framvörður í próunar- og umbótastarfi“ eins og einn orðaði pað. Umbótastarf snýst um að breyta kennsluháttum og gera pá betri fyrir nemendur og kennara, pví er athyglisvert að kennarar aðgreini pessa tvo mikilvægu pætti kennarastarfsins.

Í viðtölum við kennara í próunarteymi Fjallaskóla sögðu peir frá innleiðingarferli nokkurra verkefna og verður sagt frá tveimur peirra hér. Fyrra verkefnið hófst að frumkvæði eins kennara í hópnum fyrir u.p.b. sjö árum og er nú talið vera mikilvægur páttur í skólastarfinu. Verkefnið fólst í breytingum á kennsluháttum í stærðfræði. Forsprakki pess sagði innleiðinguna hafa tekið tvær stórar dýfur síðan byrjað var að vinna að henni, ,pá höfum við sett mannskap í að passa upp á stigin ... og matreiða ... ofan í liðið“. Degar á móti blés var kennurum boðinn meiri stuðningur, verkefnið var einfaldað og gert aðgengilegra fyrir kennara. Að lokum var námsefnið gefið út, sem er væntanlega mikil viðurkenning fyrir kennarana sem tóku pátt í að móta pað og innleiða. 
Próunarteymið vitnar í viðhorfskönnun meðal kennara sem sýndi að yfirgnæfandi meirihluti peirra myndi ekki vilja missa petta verkefni úr skólastarfinu. Eins og staðan er nú hefur forsprakki verkefnisins ekki purft að fylgja pví eftir síðustu fjögur árin og pað pví orðið sjálfbært.

Seinna próunarverkefnið frá Fjallaskóla var um innleiðingu nýrra kennsluhátta á miðstigi og unglingastigi í samræmi við skólastefnu sveitarfélagsins. Nokkrir kennarar og stjórnendur auk verkefnastjóra frá skólaskrifstofunni sátu í innleiðingarteymi skólans. Í upphafi var almenn ánægja með hugmyndina. Kennari sagði:

Ég myndi meta pað ... að flestir væru hlynntir pessu ... petta kemur sem pólitísk ákvörðun. ... Рað er aðallega að fólki finnst pað ekki hafa neitt með petta að segja. Рað á ekkert í ákvörðuninni.

Dó svo að kennarar hefðu almennt verið ánægðir með stefnu bæjarins um breytta kennsluhætti, fundu peir fyrir valdleysi og prýstingi að ofan. Umsjónarmaður verkefnisins í skólanum sagði frá tilmælum um æfingar sem kennarar fengu frá innleiðingarteyminu og fóru öfugt 1 pá. Hann sagði að kennarar vildu fá að stýra pví sjálfir hversu hratt peir færu í innleiðinguna og að hve miklu leyti peir styddust við nýju kennsluhættina.

Meðlimir í próunarteymi Fjallaskóla töldu að skólapróun og stefnumótun sveitarfélagsins pyrfti oftar að taka mið af pví sem væri að gerast úti í skólunum. Peir sögðu að skólaskrifstofan tæki stundum aðra stefnu en flestir ynnu eftir. Nú vinnur til dæmis meiri hluti skóla í sveitarfélaginu eftir sömu læsisstefnunni undir leiðsögn sérfræðinga frá einum háskólanna, en skólaskrifstofan hefur gefið út stefnu sem stangast á við hana. Slík vinnubrögð auka togstreitu milli skólamálayfirvalda og skóla. Degar faglegt starf kennara og próunarstarf sem hefur farið fram í samvinnu margra skóla í sveitarfélaginu er sniðgengið á pennan hátt, getur verið að pað hafi meiri áhrif á viljaleysi kennara til próunar- og umbótastarfs en skortur á tíma og fjármunum.

Meðlimir í próunarteymi Skriðuskóla lýstu yfir ánægju með stefnu sveitarfélagsins í skólamálum. Skólastjórinn sagði: „Við mætum velvild og pað ríkir traust frá fræðslunefnd, til stjórnenda, niður til kennara, nemenda og foreldra." Hann sagði skólastefnuna uppbyggilega og unna í samstarfi við skólasamfélagið. Í Skriðuskóla er árleg kynning fyrir nýja kennara um „,hvernig pað er að kenna í teymi og hvernig pað er frábrugðið pví að kenna inni í bekkjarstofu“", en skipulag kennslu í skólanum er um margt frábrugðið pví sem er annars staðar. Skólastjórinn sagði „,styrkleika skólans ... opin rými og teymisvinnu“ og að hans mati stuðlaði opinn skóli að samvinnu og væri „,veigamikill páttur í skólapróun“. Með pví að fylgjast með kennsluháttum samkennara og skipuleggja kennsluna saman læra kennarar hver af öðrum. Alla jafna vinna kennarateymi hvers árgangs saman að próun kennslu í árganginum; í teymunum er ekki önnur verkaskipting en sú sem kennarar koma sér sjálfir saman um. Skólastjórinn sagði hlutverk allra vera að ,ýta undir jákvæð samskipti og klappa hvert öđru á bakið“ eins og eftirfarandi ummæli bera með sér:

Partur af pví að halda í pennan góða starfsanda er að slá sér svolítið á brjóst og vera svoldið í skjallsambandi hvort við annað og foreldra. Benda á pað sem vel er gert og tala um pað sem vel er gert ... standa vörð um pað sem okkur pykir vænt um hér í skólanum.

Ef marka má pessi orð er pað ekki tilviljunum háð hvernig tekst að viðhalda skólastefnunni. Markvisst er reynt að orða pað sem vel gengur og upplýsa aðra um pað sem vel tekst í skólasamfélaginu, viðhalda góðum samskiptum og standa vörð um jákvæða hluti í skólastarfinu. Degar slíkur starfsandi smitar úr frá sér til foreldra eykur pað tiltrú peirra á gæðum skólastarfsins. Hugmyndir að próunarverkefnum í skólanum koma oftar en ekki frá kennurum og yfirstjórnin reynir að styðja við og gefa svigrúm fyrir próunarstarfið. Skólastjórinn sagði að „,neistinn sem hver kennari hefur“" skipti öllu máli pegar kæmi að pví að vinna próunarstarf sem nýttist í kennslu, pess vegna ætti petta hlutverk heima hjá kennurum. 


\section{Samantekt á helstu niðurstöðum}

Niðurstöður benda til að sveitarfélögin bregði fyrir sig ólíkum vinnubrögðum við mótun skólastefnunnar sem stjórnast af vægi sjónarmiða kjörinna fulltrúa í stefnumótun og hversu náið samstarf skólaskrifstofur hafa við skólasamfélagið. Helstu præðir um petta eru birtir í Töflu 3 og er augljóst að Skriðuvík nálgast stefnumótun með talsvert öðrum hætti en hin sveitarfélögin tvö. Dar var unnið eftir hugmyndafræði faglegs lærdómssamfélags kennara og virtist ríkja meira traust milli aðila í skólasamfélaginu.

Tafla 3. Yfirlit yfir helstu niðurstöður.

\begin{tabular}{|c|c|c|c|}
\hline $\begin{array}{l}\text { Sveitarfélag / } \\
\text { skóli }\end{array}$ & $\begin{array}{l}\text { Reynisvogur / } \\
\text { Reynisskóli }\end{array}$ & $\begin{array}{l}\text { Fjallabær / } \\
\text { Fjallaskóli }\end{array}$ & $\begin{array}{l}\text { Skriðuvík / } \\
\text { Skriðuskóli }\end{array}$ \\
\hline $\begin{array}{l}\text { Hvernig verður } \\
\text { skólastefna til? }\end{array}$ & $\begin{array}{l}\text { Varð aðallega til á } \\
\text { skólaskrifstofunni } \\
\text { og hjá pólitískum } \\
\text { yfirvöldum. }\end{array}$ & $\begin{array}{l}\text { Frumkvæði kom } \\
\text { gjarna frá pólitískum } \\
\text { yfirvöldum. Hópar } \\
\text { innan skólans vinna } \\
\text { að stefnumótun. }\end{array}$ & $\begin{array}{l}\text { Áhersla á að fá sem } \\
\text { flesta að borðinu, } \\
\text { áherslur komu fremur úr } \\
\text { skólasamfélaginu en frá } \\
\text { pólitískum yfirvöldum. }\end{array}$ \\
\hline $\begin{array}{l}\text { Hve } \\
\text { innl } \\
\text { hátt }\end{array}$ & $\begin{array}{l}\text { Áhersla á sjálfstæði } \\
\text { skólanna. Kennarar } \\
\text { voru óvissir um } \\
\text { stefnuna. Mörg } \\
\text { verkefni í gangi. }\end{array}$ & $\begin{array}{l}\text { Skólaskrifstofa vann } \\
\text { pétt með skólastjórum } \\
\text { að innleiðingu. } \\
\text { Skólunum tryggður } \\
\text { stuðningur í formi } \\
\text { kennslurádgjafar. }\end{array}$ & $\begin{array}{l}\text { Ekki formlegt } \\
\text { innleiðingarferli, heldur } \\
\text { stöðugt samstarf til } \\
\text { umbóta. Áhersla á } \\
\text { frumkvæði kennara og } \\
\text { stjórnenda. }\end{array}$ \\
\hline $\begin{array}{l}\text { Hvernig } \\
\text { birtast áhrif } \\
\text { skólastefnunnar } \\
\text { í viðhorfum } \\
\text { kennara og } \\
\text { skólastarfi? }\end{array}$ & $\begin{array}{l}\text { Skólastjóri og kennarar } \\
\text { upplifðu prýsting um } \\
\text { innleiðingu á mörgum } \\
\text { verkefnum, töldu sig } \\
\text { ekki hafa yfirsýn yfir } \\
\text { til hvers væri ætlast. }\end{array}$ & $\begin{array}{l}\text { Kennarar kvörtuðu } \\
\text { yfir of mikilli } \\
\text { stýringu. Áherslur } \\
\text { oft ekki í samræmi } \\
\text { við vilja kennara og } \\
\text { stjórnenda. }\end{array}$ & $\begin{array}{l}\text { Ánægja með stefnu } \\
\text { sveitarfélagsins, } \\
\text { gagnkvæmt traust ríkti. } \\
\text { Kennarar stjórnuðu } \\
\text { pví sjálfir hvað peir } \\
\text { innleiddu og hvernig. }\end{array}$ \\
\hline
\end{tabular}

Í Reynisvogi virtist sem skortur væri á samvirkni á pessum tíma og ekki heildstæð stefna enda töldu kennarar og stjórnendur sig ekki hafa yfirsýn. Í Fjallabæ var pessu öfugt farið, par var skýr stefna og stuðningur við skólana í boði en kennarar upplifðu jafnvel of mikla stýringu. Í öllum sveitarfélögunum kom fram að bæði fræðslustjórar og skólastjórar höfðu mikinn metnað fyrir pví að halda úti árangursríku skólastarfi og vildu standa vel að pví. Peir lýstu einnig áhyggjum af misjöfnum gæðum kennslunnar innan hvers skóla.

\section{Umræða}

Markmið pessarar rannsóknar var að öðlast skilning og pekkingu á pví hvernig samvirkni í stefnumótun í skólamálum birtist í premur sveitarfélögum á Íslandi, með pví að varpa ljósi á samskiptaform og vinnubrögð sem gætu stuðlað að eflingu og varanleika umbótastarfs. Leitað var eftir upplýsingum um samvirkni í stefnumótun sveitarfélaga og skóla og spurt um hvernig skólastefna yrði til, hvaða aðferðum væri beitt við innleiðingu hennar og hvernig hún skilaði sér inn í skólana. Rétt er að taka fram að niðurstöðurnar ná aðeins til umræddra priggja sveitarfélaga og skóla á peim tíma sem gagna var aflað og pví ekki hægt að alhæfa yfir á önnur sveitarfélög né heldur um viðkomandi sveitarfélög par sem aðstæður kunna að hafa breyst. Sveitarfélögin eru ólík bæði hvað varðar stærð, legu, pólitískar áherslur og fyrri sögu. Hér er einkum ætlunin að draga lærdóm um hvernig ferli umbóta frá stefnumótun og inn í daglegt starf birtist og um möguleg áhrif ólíkra vinnubragða á hvort og pá með hvaða hætti stefna sveitarfélags birtist í starfi og viðhorfum kennara. 
Рað vekur athygli hve ólíkri nálgun sveitarfélögin beittu við stefnumótun og innleiðingu sem undirstrikar mikilvægi pess að taka tillit til aðstæðna á hverjum stað við ákvarðanir um breytingar eins og Anna Kristín Sigurðardóttir (2019) bendir á. Að sama skapi virtust kennarar upplifa skilaboð frá fræðsluyfirvöldum með ólíkum hætti. Detta kemur ekki á óvart pví pessi mismunur hefur verið að próast hér á landi frá bví að ábyrgð á rekstri grunnskólanna var flutt fá ríki til sveitarfélaga árið 1996 (Guðmundur Ó. Ásmundsson o.fl., 2008; Sigríður Sigurðardóttir, Anna Kristín Sigurðardóttir og Börkur Hansen, 2018).

Degar horft er sérstaklega á pað sem lýtur að samvirkni sem grundvelli að farsælu umbótastarfi (Hopkins o.fl., 2014; Fullan og Quinn, 2016), má álykta að pað hafi tekist nokkuð vel til í Skriðuvík. Par mátti greina víðtækara samráð og virkara samband milli fræðsluyfirvalda og skóla sem fellur vel að skoðun Robinson og félaga (2017) um að samræða sé líklegust til að byggja upp samvirkni í menntakerfinu, sem virtist meiri í Skriðuvík en í hinum sveitarfélögunum tveimur. Dau leggja reyndar áherslu á að sambærileg samræða eigi sér stað á öllum stigum skólakerfisins og ætti að hverfast um rýni í hlutlæg gögn sem sýna fram á frammistöðu og framfarir nemenda. Gögnum um skólastarfið var safnað í öllum sveitarfélögunum og í skólunum en nýting peirra virðist hafa verið markvissust í Skriðuvík.

Hugmyndafræði lærdómssamfélagsins, eins og Anna Kristín Sigurðardóttir (2013) lýsir henni, birtist skýrt í Skriðuvík par sem ekki er um eiginlegt innleiðingarferli að ræða samkvæmt fræðslustjóra heldur hefur umbótaferlið byggt á stöðugri samræðu og samráðsferli eins og Robinson (2018) leggur til. Einnig virtist sem traust kennara til fræðsluyfirvalda hafi verið hvað mest í Skriðuvík af sveitarfélögunum premur. Sameiginleg hugmyndafræði skóla og sveitarfélaga styrkir bæði innleiðingarferlið og grundvöll próunarstarfsins. Pegar próunar- og umbótastarf byggir á sameiginlegri hugmyndafræði, trausti milli samstarfsaðila og trú peirra á hæfni hver annars, hafa pessir aðilar heildræn áhrif á próunar- og umbótastarf og virka sem samverkandi afl á menntun nemenda (Cowan o.fl., 2012; Fullan og Quinn, 2016; Hargreaves og Shirley, 2012). Robinson og fleiri (2017) taka undir petta og segja að samvirkni sé best tryggð í samræðu og samráði aðila pví kennarar séu peir sem vita best hvaða aðferðir eru líklegastar til að gagnast peirra nemendum.

Í opinberum gögnum er lögð áhersla á víðtækt samráð um stefnumótun um skólamál sem grundvöll pess að innihald stefnunnar nái til nemenda. Niðurstöður rannsóknarinnar benda til að par sem kennarar taka pátt í öllu stefnumótunarferlinu virðist innleiðing stefnunnar ganga mun betur fyrir sig en pegar hún kemur sem tilskipun frá skólamálayfirvöldum. Dað styður ábendingar Amalíu og félaga (2006) um dreifða forystu og sameiginlega ákvarðanatöku. Dað vakti athygli að kennarar virtust síður axla ábyrgð á innleiðingu skólastefnunnar og gera meiri kröfur til innleiðingarferlisins pegar stefnan kom gegnum skólaskrifstofu og frá stjórnvöldum. Tvö próunarteymi ræddu um ónógan undirbúning af hálfu sveitarfélagsins við innleiðingu skólastefnunnar á sama tíma og fræðslustjórar sögðu frá miklu kynningarstarfi, námskeiðum og málpingum. Degar kennarar mættu hindrunum voru peir fljótir að skella skuldinni á fræðslustjóra og hans fólk og gáfust jafnvel upp. Aftur á móti gerðu sömu kennarar ekki slíkar kröfur pegar peir áttu frumkvæði að umbótunum. Pá lögðu peir allt í sölurnar til pess að láta verkefnin ganga upp, voru sveigjanlegir í starfi, veittu peim stuðning sem á purftu að halda og aðlöguðu innleiðinguna аð аðstæðum hverju sinni. Petta er í samræmi við niðurstöður annarra rannsókna (Börkur Hansen, 2013; Hargreaves og Fullan, 2012; Hord og Roy, 2014) um að kennarar séu líklegri til að vinna af sannfæringu og trúa á eigin hæfni, pegar peim finnast verkefnin nauðsynleg og eiga hlutdeild í peim. Við of mikinn prýsting ofan frá fannst kennurum peir missa vald yfir eigin starfi, ekki standast kröfur sveitarfélagsins og sumir settu sig upp á móti stefnunni. Fullan (2016) heldur pví fram að pegar kennarar upplifa slíka „top-down“ stjórnunarhætti sé erfitt að ná til peirra og ósennilegt að ásættanlegum árangri verði náð. Deir upplifi jafnvel slíka nálgun sem ógnun við hugmyndir peirra um fagmennsku og faglega dómgreind (Milner, 2013). Til pess að skapa samvirkni um próunar- og umbótastarf purfa aðgerðir að hafa augljósan tilgang og vera góð eða nauðsynleg viðbót við skólastarfið. Stefnan parf að vera skýr, vinnubrögð vel 
skipulögð, ferlið gagnsætt, vel fylgst með árangri og ferlið í stöðugri endurskoðun (Fullan og Quinn, 2016). Dar sem samskipti milli sveitarfélags og skóla voru lítil ríkti tortryggni sem rýrði möguleika skólastefnu sveitarfélagsins í að hafa áhrif á skólastarfið og samvirknin var mun minni. Viðvarandi sambandsleysi parna á milli gerði pað að verkum að umbótapörfin hlóðst upp og verkefnin urðu óyfirstíganleg.

Dað vakti athygli í rannsókninni að ekki pótti öllum kennurum pað vera í sínum verkahring að stuðla að skólapróun. Sérstaklega í tveimur skólum mátti greina tregðu til pess að taka að sér ábyrgðarhlutverk eða forystu í umbótastarfi. Dar töluðu kennarar um að peir vildu heldur standa vörð um pann pátt kennarastarfsins sem sneri að nemendum og undirbúningi kennslu. Petta er athyglisvert sjónarmið par sem fáar stéttir myndu sampykkja að aðrir sæju um að próa starf sitt. Hargreaves og Shirley (2012) telja að kennarar verði að vera tilbúnir að taka pátt í stefnumótun og umbótastarfi pví annars komi um pad fyrirskipanir ofan frá. Einnig má líta á petta sem merki um að kennarar hafi ekki séð tilgang í viðkomandi verkefnum og að peim hafi ekki pótt bau líkleg til góðs fyrir peirra nemendahóp. Robinson (2018) bendir á að kröfur um breytingar sem ekki fela í sér umbætur fyrir nemendur geti verið tímasóun að mati kennara sem fyrst og fremst bera hag nemenda sinna fyrir brjósti. Yfirvöld ættu að hafa petta í huga pegar menntaumbætur eru skipulagðar og skapa kennurum og stjórnendum tækifæri til að taka virkan pátt í stefnumótun og umbótastarfi.

Heiltæk nálgun til umbóta gengur út á að huga að öllum páttum skólastarfsins svo peir lendi ekki á skjön hver við annan, að eitt vinni gegn öðru pannig að tilætlaður árangur náist ekki og krefst pví samvinnu og samræðna til að tryggja sameiginlegan skilning (Robinson o.fl., 2017). Til pess að ná fram heiltækri nálgun til umbóta parf lærdómssamfélagið að teygja anga sína frá fræðsluyfirvöldum til nemenda (Cowan o.fl., 2012). Auðvelt er að taka undir með Fullan (2010) sem bendir á að slík samræming sé flókin og tímafrek og erfitt að sjá fyrir sér hvernig hún fari fram í raun. Starfshættir í Skriðuvík eru eitt dæmi sem læra má af, en Robinson og félagar (2017) benda einnig á að kennarar séu peir aðilar sem vita best hvað gagnist peirra nemendum best. , en pó einungis eftir að hafa rýnt markvisst í frammistöðu peirra. Ef til vill mætti byrja parna, tryggja ¡ð umræðan hverfist ætíð um menntun og nám barnanna með stuðningi hlutlægra gagna.

Eitt er víst að byggja parf upp traust svo aðilar sem koma að skólastarfinu tali saman og hlusti hver á annan. Við skólapróun purfa menntamálayfirvöld enn frekar að taka mið af núverandi skólastarfi og nýta sér betur pekkingu kennara. Ef heiltæk nálgun til umbóta á að verða að veruleika væri æskilegt að leiðin milli skólaskrifstofu og skóla styttist og auðveldara væri fyrir kennara að nálgast ráð og sértæka pjónustu pegar peir pyrftu á henni að halda. Dessi nálgun er pá háð pví að skólaskrifstofurnar hafi á að skipa nægum mannafla sem hefur faglegar forsendur til að sinna ráðgjöf og traust ríki milli skóla og skólaskrifstofu. 


\section{Coherence and Collaboration in School development and System Improvement}

Policy planning in education is an important and complicated undertaking that demands systematic work and extensive co-operation between actors to ensure successful implementation. In this matter, many consider coherence and collaboration to be the basis for successful educational development efforts that lead to increased achievement in student learning (Hopkins, Stringfield, Harris, Stoll, \&Mackay, 2014; Robinson, 2018). The aim of the research discussed in this paper is to gain understanding and knowledge of how this coherence appears in policy work in three municipalities in Iceland and in one school in each of the municipalities. The focus is on how local government policy and methods of implementation might support or hinder sustainable school improvements and how they might appear in school practices on a daily basis.

The discussion is based on educational leadership theories that encourage a systemic approach to reform, encompassing all levels of the system and different areas, such as curriculum, teaching methods, leadership, and families. This systematic approach is meant to support the coherence of all entities that influence teaching and learning (Fullan \& Quinn, 2016) and enhance teacher leadership and the professional skills of those working towards the same purposes. Coherence is achieved through collaboration and communication between actors at different levels rather than through checklists or strict surveillance (Robinson et al., 2017).

Data was collected by interviewing school district leaders in the three municipalities, one school principal from each municipality, and one development team from each school in the respective municipalities. The developmental teams consisted of four to six teachers, leaders, and department heads in the school. Other data included the documents addressing the policies of districts and schools. The data was analysed by seeking information on the following themes: (1) the making of the policies; e.g., where did it originate from and who participated; (2) the methods by which the policies were implemented in schools; and (3) how the policies actually influenced classroom practices.

The results revealed that coherence in policy and school development was more apparent in one of the municipalities than in the other two. There, an approach emphasizing a professional learning community was used to decide on policy issues and methods of implementation. This approach was openly discussed by interviewed participants. The principal practised instructional leadership, teachers were included in decision making, and communication between schools and school district leaders was based on professional discussion and mutual trust to a greater extent than in the other two municipalities. There, policy decisions were most often taken by politicians or at the central school office and presented and discussed with teachers and leaders in the schools. The teachers felt overwhelmed by requirements for implementing many different projects and complained about lack of preparation and support. As such, the Robinson, Bendikson, Mcnaughton, Wilson, \& Zhu (2017) findings about the importance of communication in order to enhance coherence were supported.

It should be noted that the findings only apply to the three municipalities and schools at the time when data was collected and therefore cannot be generalized to other municipalities nor to the relevant municipalities where circumstances may have changed. The municipalities differ in size, position, political focus, and history; therefore, they should not be compared. The intention was to learn about how the process of implementation from policy making to day-to-day schoolwork is achieved as well as whether and how a municipality's policy is reflected in the work and 
attitudes of teachers. The results should be beneficial for school authorities, school districts, and schools and further encourage a collaborative approach in educational development.

Key words: School development, Coherence, Systemic improvement, Distributed leadership, Professional learning community

\section{Um höfundana}

Helga Sigríður Dórsdóttir (helgath@msund.is) lauk MA-prófi í stjórnunarfræðum menntastofnana vorið 2017, stundaði nám í félagsfræði, uppeldisfræði og sögu á árunum 1994-1999 við KTI í Dýskalandi, lauk BA-gráđu í pýsku og félagsfræði við HÍ 2003 og kennsluréttindum ári síðar. Helga kenndi félagsfræði við Menntaskólann við Reykjavík frá 2004 til 2009 og starfaði sem leikskólakennari í Noregi i 6 ár. Helga hefur verið konrektor Menntaskólans við Sund síðan haustið 2017.

Anna Kristín Sigurðardóttir (aks@hi.is) er prófessor við Menntavísindasvið Háskóla Íslands, formaður námsbrautar um menntastjórnun og matsfræði og ábyrgðarmaður Rannsóknarstofu um próun skólastarfs. Hún er með B.Ed.-gráđu í grunnskólakennslu og M.Ed.-gráđu frá Kennaraháskóla Íslands. Doktorsgráđu lauk hún frá Háskólanum í Exeter árið 2006 á sviði menntastjórnunar. Rannsóknarsvið hennar tengjast menntastjórnun, skólapróun, lærdómssamfélagi og námsumhverfi skóla og tengslum við kennsluhætti.

\section{About the authors}

Helga Sigríður Dórsdóttir (helgath@msund.is) acquired her MA degree in educational leadership from the University of Iceland in 2017. During the years of 1994 - 1999 she studied sociology, pedagogy and history in KTI in Germany and completed a bachelor's degree in German and sociology from the University of Iceland in 2003, obtaining a teaching license one year later. Helga taught sociology at the Reykjavík Upper Secondary School from $2004-2009$ and worked as a preschool teacher in Norway for six years after that. In 2017, Helga accepted the position of deputy headmaster in Sund Upper Secondary School in Reykjavík.

Dr Anna Kristín Sigurðardóttir is a professor at the University of Iceland, School of Education. She is currently a head of department for educational leadership and school evaluation and a head of the Research Centre of Educational Development. She holds a B.Ed. in teaching, an M.Ed. in special education and a Ph.D. in educational leadership from the University of Exeter in the UK. Her research interests concern leadership, systemic and school development, the professional learning community and the link between space and teaching and learning. 


\section{Heimildir}

Amalía Björnsdóttir, Börkur Hansen og Ólafur H. Jóhannesson. (2006). Mótun skólastarfs - Hver er hlutur kennara? Tímarit um menntarannsóknir, 3, 12-26.

Anna Kristín Sigurðardóttir. (2013). Skóli sem lærdómssamfélag. Í Rúnar Sigpórsson, Rósa Eggertsdóttir og Guðmundur Heiðar Frímannsson (ritstjórar), Fagmennska í skólastarfi. Skrifað til heiðurs Trausta Dorsteinssyni (bls. 35-55). Reykjavík

Anna Kristín Sigurðardóttir. (2019). PISA - Hvað svo? Nokkur leiðarstef um innleiðingu menntaumbóta. Sérrit Netlu 2019 - Alpjóðlegar menntakannanir. Sótt af http://netla.hi.is/serrit/2019/altjodlegar_menntakannanir/04.pdf

Ash, R. C. og Hodge, P. H. (2016). Five critical leadership practices. The secret to high-performing schools. New York, NY: Routledge.

Berglind Rós Magnúsdóttir. (2015). Erfitt að vinda ofan af einkavæðingu. Skólavarðan, 15(5), 15-22.

Birna Sigurjónsdóttir og Börkur Hansen. (2014). Gildi og áherslur skólastjóra í grunnskólum í Reykjavík. Netla - Veftímarit um uppeldi og menntun. Sótt af http://netla.hi.is/greinar/2014/ryn/001.htm

Björk Ólafsdóttir. (2010). Skólastefna sveitarfélaga. Handbók. Sótt af http://www.samband.is/media/stefnumotun-i-skolamalum/Skolastefna-stora.pdf

Braun,V. og Clarke,V. (2013). Successful qualitative research, a practical guide for beginners. London: SAGE.

Börkur Hansen. (2013). Forysta og skólastarf. Í Rúnar Sigpórsson, Rósa Eggertsdóttir og Guðmundur Heiðar Frímannsson (ritstjórar), Fagmennska í skólastarfi. Skrifað til heiðurs Trausta Dorsteinssyni (bls. 77-93). Reykjavík: Háskólaútgáfan.

Campbell, L., Liebermann, A. og Yashkina, A. (2016). Developing professional capital in policy and practice: Ontario's teacher learning and leadership program. Journal of Professional Capital and Community, 1(3), 219-236. doi:10.1108/JPCC-03-2016-0004

Cowan, D., Joyner, S. og Beckwith, S. (2012). Getting serious about the system. A fieldbook for district and school leaders. Thousand Oaks, CA: Corwin.

Dogan, S. og Adams, A. (2018). Effect of professional learning communities on teachers and students: Reporting updated results and raising questions about research design. School Effectiveness and School Improvement, 29(4), 634-659. doi:10.1080/09243453.2018.1500921

DuFour, R. og DuFour, R. (2012). The school leader's guide to professional learning communities at work. Bloomington: Solution Tree Press.

Erla Björg Gunnarsdóttir. (2014, 21. júní). Kennarasambandið gagnrýnir Hvítbók menntamálaráðherra. Visir.is. Sótt af http://www.visir.is/kennarasambandid-gagnrynir-hvitbok-menntamalaradherra/article/2014706219974

European Agency for Special Needs and Inclusive Education. (2017). Menntun fyrir alla á Íslandi. Sótt af https://www.stjornarradid.is/media/menntamalaraduneyti-media/media/frettatengt2016/final-report_external-audit-of-the-icelandic-system-for-inclusive-education.pdf

Fullan, M. (2010). All systems go. The change imperative for whole system reform. Thousand Oaks, CA: Corwin.

Fullan, M. (2016). The new meaning of educational change (5. útgafa). New York, NY: Teacher College Press.

Fullan, M. og Quinn, J. (2016). Coherence. The right drivers in action for schools, districts and systems. Thousand Oaks, CA: Corwin.

Gerður G. Óskarsdóttir (ritstjóri). (2014). Starfshœettir í grunnskólum við upphaf 21. aldar. Sótt af http://menntavisindastofnun.hi.is/sites/menntavisindastofnun.hi.is/files/throunskolastarfs/starfshaettir_heild_m_ kapu_02102015_lr.pdf

Guðmundur Ó. Ásmundson, Börkur Hansen og Ólafur H. Jóhannsson. (2008). Stjórnskipulag grunnskóla. Hugmyndir skólanefnda um völd sín og ábyrgð. Netla - Veftímarit um uppeldi og menntun. Sótt af http:// netla.hi.is/greinar/2008/010/index.htm

Hargreaves, A. og Fullan, M. (2012). Professional capital. Transforming teaching in every school. New York, NY: Teachers College Press.

Hargreaves, A. og Shirley, D. (2012). The global fourth way. The quest for educational excellence. Thousand Oaks, CA: Corwin.

Hargreaves, D. (2010). Creating a self-improving school system. Sótt af https://www.gov.uk/government/uploads/ system/uploads/attachment_data/file/325873/creating-a-self-improving-school-system.pdf 
Harris, A. (2013). Distributed leadership: Friend or foe? Educational Management Administration E Leadership, 41(5), 545-554. doi:10.1177/1741143213497635

Háskóli Íslands. (e.d.). Heiltak nálgun að umbótum - skóli sem lacrdómssamfélag. Sótt af http://menntavisindastofnun.hi.is/throun_skolastarfs/heiltaek_nalgun_ad_umbotum_skoli_sem_laerdossamfelag

Hopkins, D. (2001). School improvement for real. London: Routledge.

Hopkins, D., Stringfield, S., Harris, A., Stoll, L. og Mackay, T. (2014). School and system improvement: A narrative state-of-the-art review. School Effectiveness and School Improvement, 25(2), 257-281. doi:10.1080 /09243453.2014.885452

Hord, S. M. (2004). Learning together, leading together. Changing schools through professional learning communities. New York, NY: Teachers College Press.

Hord, S. M. og Roy, P. (2014). Creating learning communities. Í S. M. Hord og P. Roy (ritstjórar), Reach the highest standard in professional learning: Learning communities (bls. 19-60). London: SAGE.

Hoy, W. K. og Miskel, C. G. (2013). Educational Administration: Theory, research and practice. New York, NY: McGraw-Hill.

Ingólfur Ásgeir Jóhannesson. (2013). Grunnskólakennarar í aftursætinu og leikskólakennarar í skottinu? Hlutverk og fagmennska kennara í stefnu ríkis og sveitarfélaga. Í Rúnar Sigpórsson, Rósa Eggertsdóttir og Guðmundur Heiðar Frímannsson (ritstjórar), Fagmennska í skólastarfi. Skrifað til heiðurs Trausta Dorsteinssyni (bls. 131-153). Reykjavík: Háskólaútgáfan.

Katrín Blöndal og Sigríður Halldórsdóttir. (2013). Úrtök og úrtaksaðferðir í eigindlegum rannsóknum. Í Sigríður Halldórsdóttir (ritstjóri), Handbók í aðferđafræði rannsókna (bls. 129-136). Akureyri: Háskólinn á Akureyri.

Lambert, L. (2006). Lasting leadership: A study of high leadership capacity schools. The Educational Forum, 70, 238-254. Sótt af http://files.eric.ed.gov/fulltext/EJ735836.pdf

Lög um grunnskóla nr. 91/2008.

Menntamálastofnun. (2019). PISA 2018. Helstu niðurstöður á Íslandi. Reykjavík: Höfundur.

Mennta- og menningarmálaráđuneytið. (2011). Aðalnámskrá grunnskóla: Almennur hluti 2011. Reykjavík: Höfundur.

Milner, H. R. (2013). Policy reforms and de-professionalization of teaching. Sótt af http://nepc.colorado.edu/ publication/policy-reforms-deprofessionalization

Ólafur H. Jóhannsson. (2013). Skólamenning og skólapróun í ljósi nýrrar Aðalnámskrár grunnskóla. Í Rúnar Sigpórsson, Rósa Eggertsdóttir og Guðmundur H. Frímannsson (ritstjórar), Fagmennska í skólastarfi. Skrifað til heiðurs Trausta Dorsteinssyni (bls. 153-168). Reykjavík: Háskólaútgáfan.

Robinson,V. (2018). Reduce change to increase improvements. Thousand Oaks, CA: Corwin.

Robinson, V., Bendikson, L., Mcnaughton, S., Wilson, A. og Zhu, T. (2017). Joining the dots: The challenge of creating coherent school improvement. Teacher College Record, 119, 1-44.

Robinson, V., Hohepa, M. og Lloyd, C. (2009). School leadership and student outcomes: Identifying what works and why. Sótt af https://www.educationcounts.govt.nz/_data/assets/pdf_file/0015/60180/BES-Leadership-Web-updated-foreword-2015.pdf

Sigríður Sigurðardóttir, Anna Kristín Sigurðardóttir og Börkur Hansen. (2018). Educational leadership at municipality level. Nordic Journal of Comparative and International Education, 2(2-3), 56-71. doi:10.7577/ njcie. 2760

Skólamálaráð Kennarasambands Íslands. (2016). Umræðuhefti um menntamál. Sótt af http://www.ki.is/images/ Skrar/KI/Skolamal/Hvitbok/Umruhefti_Sklamlars_K_um_menntml_28_janar_2016.pdf

Porlákur Axel Jónsson. (2014, 21. nóvember). Viljum við lesskilning? Fréttablaðið, bls. 22.

Helga Sigríður Dórsdóttir og Anna Kristín Sigurðardóttir. (2020).

Samvirkni og samvinna í próunar- og umbótastarfi

Netla - Veftímarit um uppeldi og menntun. Menntavísindasvið Háskóla Íslands.

Sótt af http://netla.hi.is/greinar/2020/ryn/02

DOI: https://doi.org/10.24270/netla.2020.2 